\title{
Britain prepares to leave European fast-breeder reactor programme
}

London \& Munich. Almost exactly ten years after the United States decided to abandon its efforts to develop a commercial fast breeder reactor, Britain is poised to withdraw from European attempts to achieve the same goal. Its departure could doom the entire project.

Officials at the Department of Trade and Industry were reported last week to be recommending that the British government withdraw its support from the joint European Fast Breeder (EFR) programme, begun in 1984 by Britain, France and Germany. The programme is intended to design and eventually build a reactor demonstrating the commercial feasibility of producing electricity through the action of fast neutrons. The government argues that any responsibility for proceeding with the construction of the reactor should now rest with the nuclear industry.

Official confirmation of Britain's withdrawal was expected to be announced in London this week as part of a package of public spending cuts. Given doubts about proceeding in both France and Germany, such a decision could precipitate the indefinite postponement of any attempt to construct a new fast breeder in Europe and leave Japan as the only country still committed to such a step.

The decision also casts doubt on Britain's reprocessing of spent fuel from its thermal reactors. One of the main justifications for building the Thermal Oxide Reprocessing Plant (THORP) at Sellafield has been the need to obtain plutonium for fast breeders. This justification will disappear if no fast breeders are to be built in Britain in the near future.

The original agreement set out three stages. The second - the outline design of a commercial fast breeder-- was to have been completed next March, followed by a preconstruction stage that includes an application for a construction licence. The costs are being shared by National Nuclear Corporation (NNC) in Britain, Framatome in France and Siemens in Germany. Construction was supposed to begin in 1997, although that had since been put back to the end of the decade. The three governments have also funded a parallel research programme, with Britain providing a fifth of the total funding through the Department of Trade and Industry following its merger earlier this year with the Department of Energy.

Four years ago, Britain decided to terminate funding in 1994 for its own fast-reactor research programmes based on the Proto- type Fast Reactor at Dounreay. At the time, however, it agreed to continue funding research as part of the European programme, for which it currently pays about $£ 10$ million (US\$18 million) a year.

Government officials, because of the country's economic difficulties, have now decided that even that sum is too much.

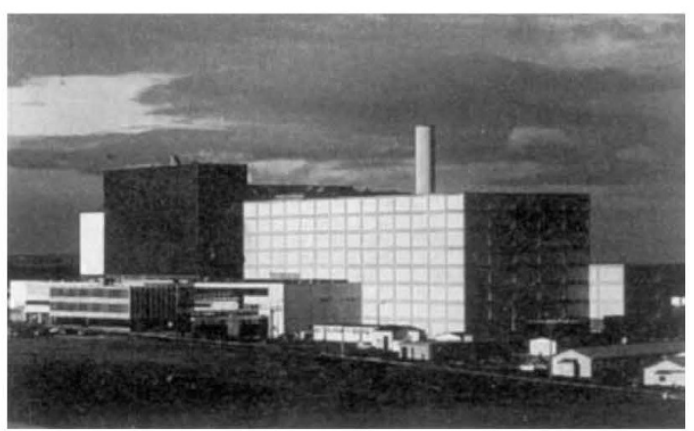

Britain's Prototype Fast Reactor at Dounreay, in Scotland, is scheduled to close in 1994.

They are planning to withdraw government funding from the European programme when the current phase ends next March - a move that will also signal Britain's withdrawal from virtually all long-term nuclear research, apart from nuclear fusion.

Energy analysts are not surprised by Britain's decision. Fast breeders are unlikely to be able to compete economically with thermal reactors until the end of the next century at the earliest, and the slowdown in the expansion of nuclear power has dimmed the prospect of a uranium shortage and the consequent need for fast reactors capable of 'breeding' their own fuel. Any decision to abandon the EFR would be welcomed by the anti-nuclear movement, which has long criticized fast reactors for their role in encouraging the spread of plutonium.

Furthermore, the privatization of Britain's electricity industry has increased efforts to find short-term solutions to the problem of energy sufficiency, and neither the government nor industry is eager to subsidize long-term commercial developments whose return remains uncertain.

Those who have been working on the fast breeder programme believe that the decision is short-sighted. They argue that, even if fast breeders are not needed until well into the next century, abandoning research at this stage would be a costly mistake.

"The NNC would be extremely dismayed and disappointed if Britain were to withdraw from the EFR programme," says Deon
Ward, general manager of NNC's fast reactor business. "We have supported this out of our own money for quite a long time. We have also developed close associations with our partner companies in other fields."

So far, Germany and France have continued to maintain their public commitment to the programme and neither is likely to dismantle its research teams immediately. However, Germany last March abandoned its own national fast breeder programme, based on the SNR-300 reactor at Kalkar, following the reactor's failure to obtain an operating licence from Social Democrat local authorities. Although Germany still spends about DM45 million (US\$30 million) a year on fast breeder research, most of this is on safety studies.

Willy Marth, executive director of the management group of the EFR, said last week that the tripartite programme was likely to collapse if Britain pulls out entirely but that the collaboration could still proceed at a slower pace if Britain were somehow to remain a partner. A spokesman for Germany's research and technology ministry, the BMFT, said that Germany's position was "not fixed, although utilities are bound to be disappointed".

Jacques Rouchard, director of nuclear reactors at France's Atomic Energy Commission, said that the remaining countries will reapportion the work between them if Britain pulls out. France, which has invested heavily in its fast breeder Superphénix, is unlikely to abandon its own fast reactor programme.

But searching questions about both the economics and the safety of fast breeders have been recently raised, the first because France has a surplus supply of electricity generated by nuclear power stations, the second because of operating difficulties at Superphénix and a recent report highly critical of its safety aspects.

In Britain, intervention by the president of the Board of Trade, Michael Heseltine a keen supporter of European technological cooperation - could overrule the wishes of DTI officials. But this was considered unlikely.

"I would be very sad if we pulled out of the EFR", says Derek Jackson, professor of engineering at the University of Manchester, who has been studying the performance of fast reactors for both the NNC and AEA Technology. "It would be a shame if the whole programme was abandoned in the interests of short-term expediency."

David Dickson \& Alison Abbott 